\title{
Pengaruh current ratio, total asset turnover, dan return on assets terhadap pertumbuhan laba
}

Pipit Septiyarina

Program Studi Manajemen, Fakultas Ekonomi, Universitas Islam Kadiri, Kediri, 64128, Indonesia

\begin{tabular}{ll}
\hline INFO ARTIKEL & ABSTRAK \\
\cline { 2 - 3 } $\begin{array}{l}\text { Kata kunci: } \\
\text { Cussent ratio, total }\end{array}$ & Tujuan penelitian untuk menganalisis current Ratio berpengaruh \\
on assets, pertumbuhan & terhadap Pertumbuhan Laba, total asset turnover berpengaruh \\
laba & terhadap petumbuhan laba, dan return on assets berpengaruh \\
& terhadap pertumbuhan laba pada PT.Gudang Garam Tbk. Jenis \\
& penelitian adalah penelitian kuantitatif. Teknik pengambilan sampel \\
& dalam penelitian ini adalah teknik purposive sampling. Sampel dalam \\
& penelitian ini adalah laporan keuangan PT Gudang Garam Tbk tahun \\
& 2012-2019. Penelitian ini menggunakan data sekunder yaitu laporan \\
& keuangan tahunan. Teknik analisis menggunakan uji \\
& heteroskedastisitas, uji autokorelasi, dan uji regresi linier berganda. \\
& Hasil dalam penelitian ini menunjukan bahwa current ratio tidak \\
& berpengaruh secara parsial terhadap pertumbuhan laba, TATO tidak \\
& berpengaruh secara parsial terhadap pertumbuhan laba, ROA \\
& mempunyai pengaruh secara parsial terhadap pertumbuhan laba.
\end{tabular}

\begin{tabular}{|c|c|}
\hline ARTICLE INFO & ABSTRACT \\
\hline $\begin{array}{l}\text { Keywords: } \\
\text { Current ratio, total } \\
\text { asset turnover, return } \\
\text { on assets, profit growth }\end{array}$ & $\begin{array}{l}\text { The purpose of this study is to analyze the current ratio has an effect on } \\
\text { profit growth, total asset turnover has an effect on profit growth, and } \\
\text { return on assets has an effect on profit growth at PT. Gudang Garam } \\
\text { Tbk. This type of research is quantitative research. The sampling } \\
\text { technique in this research is purposive sampling technique. The sample } \\
\text { in this study is the financial statements of PT Gudang Garam Tbk in } \\
2012-2019 \text {. This study uses secondary data, namely the annual financial } \\
\text { statements. The analysis technique used heteroscedasticity test, } \\
\text { autocorrelation test, and multiple linear regression test. The results in } \\
\text { this study indicate that the current ratio does not partially affect profit } \\
\text { growth, TATO does not partially affect profit growth, ROA has a partial } \\
\text { effect on profit growth. }\end{array}$ \\
\hline
\end{tabular}

Korespondensi Penulis: Program Studi Manajemen Fakultas Ekonomi, Universitas Islam Kadiri, Jalan Sersan Suharmadji No. 38, Manisrenggo, Kediri 64128, Indonesia. E-mail: pipitseptiyarina@gmail.com 


\section{Pendahuluan}

Pertumbuhan laba merupakan ukuran kinerja suatu perusahaan dengan kondisi yang baik, ketika produktivitas perusahaan meningkat maka nilai perusahaan juga meningkat. Jika kinerja perusahaan baik maka tingkat pertumbuhan labanya juga akan naik, sebaliknya jika kinerja perusahaan buruk maka tingkat pertumbuhan labanya juga akan naik turun. Pertumbuhan laba yang baik menunjukkan bahwa situasi keuangan yang baik pada akhirnya akan menambah nilai bagi perusahaan.

Pertumbuhan laba yang positif dapat mencerminkan kemampuan perusahaan secara tepat dan memaksimalkan sumber daya yang dimilikinya untuk menciptakan laba bagi perusahaan, menunjukkan bahwa kinerja perusahaan baik, sebaliknya ketika pertumbuhan laba menurun atau negatif berarti perusahaan kurang mampu mengelola sumber daya dan karena itu tidak dapat membawa profit bagi perusahaan. Peningkatan pendapatan dari tahun ke tahun dapat mengukur efektivitas tata kelola perusahaan dalam memprediksi pertumbuhan pendapatan dan perkembangan usaha di masa depan.

Hal ini akan mempengaruhi keputusan investasi dan calon investor yang akan menanamkan modalnya pada perusahaan tersebut. Jika pertumbuhan laba perusahaan terus menurun dari waktu ke waktu berarti citra perusahaan kurang baik yang akan mengurangi kepercayaan investor terhadap prospek perusahaan di masa mendatang. Sebaliknya, jika pertumbuhan dan profitabilitas perusahaan terus tumbuh maka investor juga akan tertarik.

Pertumbuhan laba puncak dapat menjadi indikator keberhasilan perusahaan. Pertumbuhan laba yang baik dan terus meningkat menunjukkan bahwa status keuangan perusahaan baik, meningkatkan nilai perusahaan di mata investor. Bagi mereka yang berurusan dengan laporan keuangan tahunan, penting untuk melihat peningkatan profit perusahaan, karena jumlah profit pemegang saham akan bergantung padanya (Gunawan \& Wahyuni, 2013).

Pertumbuhan laba dapat dilihat dalam laporan keuangan, yaitu informasi keuangan tentang suatu perusahaan selama periode waktu tertentu yang digunakan untuk menggambarkan kinerja sebuah perusahaan. Tidak hanya manajer keuangan perusahaan atau pihak internal perusahaan yang membutuhkan laporan keuangan, namun beberapa pihak luar juga membutuhkan informasi tentang laporan keuangan perusahaan, yaitu calon investor dan kreditur. Masing-masing pihak memiliki kebutuhan tersendiri untuk memahami laporan keuangan perusahaan (Kasmir, 2017).

Untuk memahami informasi yang terkandung dalam laporan keuangan, perlu dilakukan analisis. Analisis yang digunakan yaitu analisis keuangan dasar yang dapat digunakan untuk menilai kekuatan dan kelemahan keuangan perusahaan. Analisis indikator keuangan perusahaan bertujuan untuk mengetahui profitabilitas (profit) perusahaan 
dan risiko kesehatan (Andriyanti, 2015). Rasio keuangan umumnya dapat dibagi menjadi likuiditas, leverage, aktivitas dan ukuran profitabilitas. Dalam penelitian ini, peneliti membatasi rasio-rasio tertentu saja yang diteliti, seperti rasio likuiditas (Current Ratio), rasio aktivitas (Total Asset Turnover) dan rasio profitabilitas (Return On Assets) (Kasmir, 2017).

Current Ratio merupakan salah satu rasio likuiditas yang digunakan untuk menilai kemampuan perusahaan dalam membayar utang temporernya dengan menggunakan aset yang ada, sehingga dapat dikatakan perusahaan tidak mampu melunasi utang jangka pendeknya jika rasio utang lancarnya berada di atas rasio utang jangka pendeknya (Kasmir, 2017).

Total Assets Turnover merupakan rasio yang membandingkan jumlah aset yang digunakan dengan jumlah penjualan yang diperoleh selama periode tertentu, ini merupakan salah satu rasio aktivitas dan mengukur berapa banyak aset yang digunakan dalam aktivitas perusahaan. rasio ini juga digunakan untuk mengukur seberapa jauh aset digunakan dalam aktivitas perusahaan (Kasmir, 2017).

Sedangkan Return on Assets (ROA) merupakan salah satu rasio profitabilitas yang dapat digunakan untuk menentukan kemampuan perusahaan dalam menciptakan profit dari aset yang digunakan dalam usaha (Kasmir, 2017). Kuantitas laba yang diciptakan dengan demikian akan meningkat secara proporsional dengan jumlah nilai Return On
Assets yang dihasilkan agar perusahaan dapat mengelola asetnya secara produktif.

Beberapa penelitian sebelumnya telah dilakukan terhadap variabel-variabel yang mempengaruhi pertumbuhan laba, salah satunya yang dilakukan oleh Andriyanti (2015) yang menemukan bahwa Current Ratio tidak berpengaruh signifikan terhadap perkembangan laba perusahaan. Sedangkan penelitian Olfiani \& Handayani (2019), rasio lancar memiliki pengaruh yang cukup besar terhadap pertumbuhan laba suatu perusahaan.

Menurut Anugrah (2014), Total Assets Turn Over suatu perusahaan tidak berdampak besar terhadap perkembangan laba organisasi. Sedangkan menurut penelitian Utami (2018), Total Assets Turn Over memiliki dampak yang cukup besar terhadap perkembangan laba suatu perusahaan. Dalam penelitiannya Andriyanti (2015), menemukan Return On Assets mempunyai pengaruh secara signifikan terhadap pertumbuhan laba perusahaan. Sedangkan pada penelitian Fadilah (2019), menyatakan bahwa Return On Assets tidak mempunyai pengaruh yang signifikan terhadap pertumbuhan laba perusahaan.

Pada penelitian Utami (2018), yang menyatakan bahwa Return On Assets mempunyai pengaruh signifikan terhadap pertumbuhan laba perusahaan. Penelitian ini didukung juga oleh penelitian Andriyani (2015), menyatakan bahwa Return On Assets berpengaruh signifikan terhadap pertumbuhan laba perusahaan. Dari research gap di atas maka 
tujuan penelitian ini untuk menguji pengaruh current ratio, total asset turnover, dan return on asset terhadap pertumbuhan laba.

\section{Tinjauan Pustaka dan Pengembangan Hipotesis}

\subsection{Current Ratio}

Menurut Kasmir (2017, current ratio merupakan ukuran kemampuan perusahaan untuk menyelesaikan utang jangka pendek atau utang yang jatuh tempo setelah penagihan keseluruhan. Selesaikan utang darurat dalam waktu dekat. Menurut Sawir (2003), current ratio merupakan ukuran yang digunakan oleh perusahaan untuk menentukan kemampuannya dalam memenuhi kewajiban jangka pendek karena menunjukkan seberapa baik aset memenuhi persyaratan pemberi pinjaman jangka pendek.

Current ratio merupakan rasio yang digunakan untuk mengukur kemampuan perusahaan dalam menggunakan seluruh aset jangka pendek yang tersedia untuk memenuhi kewajiban jangka pendeknya, yang akan berakhir dalam waktu dekat. Dengan kata lain, rasio jangka pendek ini menggambarkan hubungan antara aset lancar yang tersedia perusahaan, kewajiban jangka pendek, dan total kewajiban jangka pendek (Hery, 2015: 178).

Rumus mencari rasio lancar atau current ratio yaitu menurut Kasmir (2017):

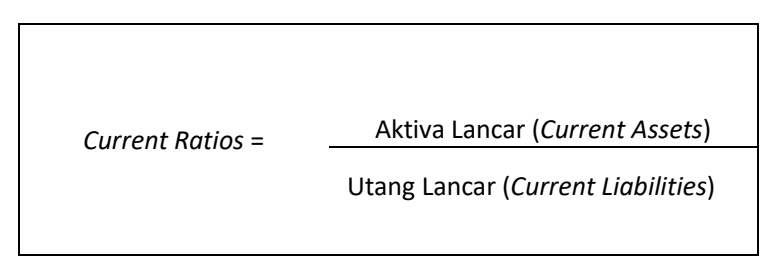

\subsection{Total Asset Turnover}

TATO merupakan rasio yang digunakan untuk mengukur pendapatan seluruh aset yang dimiliki perusahaan dan penjualan yang dihasilkan aset per rupiah, atau indikator yang digunakan untuk mengukur tingkat pemanfaatan total aset (Hamidu, 2011). TATO disebut juga dengan perputaran total aset. Hubungan ini menunjukkan efisiensi penggunaan seluruh aset perusahaan (Fahmi, 2020).

TATO atau rasio aktivitas merupakan angka kunci untuk mengukur perkembangan nilai aset suatu perusahaan. Indikator ini digunakan untuk mengevaluasi efisiensi penggunaan dan pengelolaan sumber daya perusahaan. Kemampuan untuk melakukan aktivitas seharihari seperti penjualan, penagihan, pengelolaan persediaan, pengelolaan modal kerja, dan pengelolaan seluruh aset perusahaan (Hanafi \& Halim, 2000). TATO digunakan untuk mengukur jumlah aset yang dimiliki perusahaan dan kinerja perusahaan dalam mengelola asetnya untuk meningkatkan penjualan.

Adapun rumus TATO menurut Fahmi (2020) yaitu :

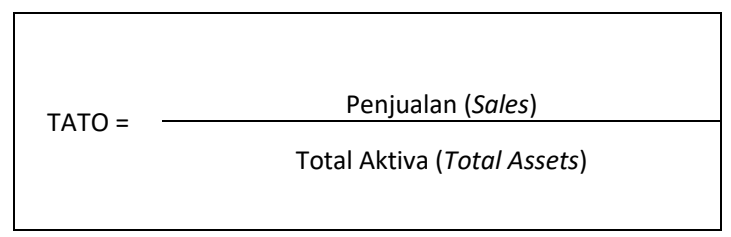

\subsection{Return on Assets}

ROA merupakan salah satu indikator profitabilitas, yang bertujuan untuk mengukur kemampuan perusahaan dalam menghasilkan laba dengan menggunakan seluruh aset yang 
ditanamkan dalam usaha perusahaan (Munawir. 2004). Rasio dari investasi tersebut dapat menghasilkan pengembalian yang diharapkan dan investasi benar-benar sesuai dengan aset investasi perusahaan (Fahmi, 2020).

ROA merupakan rasio profitabilitas yang mengukur kemampuan perusahaan untuk menghasilkan profit dari aktivitasnya. Adapun rumus ROA menurut Hery (2015) yaitu :

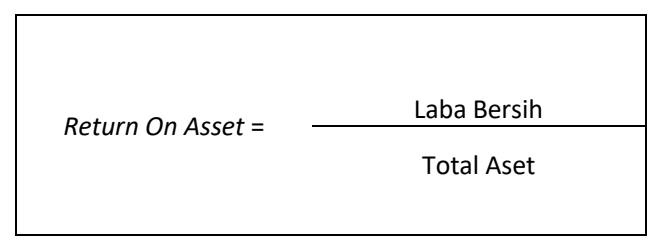

\subsection{Pertumbuhan Laba}

Laba merupakan ukuran kinerja perusahaan selama periode waktu tertentu. Semakin banyak profit yang dihasilkan, semakin efisien manajemen usaha. Estimasi ini didasarkan pada laporan keuangan tahunan perusahaan. Hal ini dapat dievaluasi berdasarkan manfaat dan biaya yang diterima. Dibandingkan dengan mengevaluasi kinerja berdasarkan kenaikan atau penurunan modal bersih, penyajian informasi laba dalam laporan keuangan merupakan arah utama kegiatan usaha, khususnya di industri perbankan. Laba juga dapat digunakan untuk memprediksi pertumbuhan pendapatan tahun depan (Fadhilah, 2019).

Pertumbuhan laba merupakan persentase pertumbuhan laba perusahaan. Cara menghitung pertumbuhan pendapatan merupakan dengan mengurangkan pendapatan saat ini dari pendapatan periode sebelumnya, kemudian membagi laba periode sebelumnya (Fadhilah,2019).

Menurut Purnamasari (2018), ada beberapa faktor yang akan mempengaruhi pertumbuhan pendapatan, antara lain: a)Ukuran perusahaan, semakin besar perusahaan, semakin akurat pertumbuhan laba yang diharapkan; b)Umur Perusahaan, perusahaan rintisan kurang berpengalaman dalam meningkatkan laba, sehingga akurasinya masih buruk; c)Leverage, ketika sebuah perusahaan berhutang banyak, manajer sering memanipulasi profit untuk mengurangi akurasi pertumbuhannya; d)Tingkat penjualan, semakin tinggi tingkat penjualan di masa lalu, semakin tinggi tingkat penjualan di masa depan dan semakin tinggi pertumbuhan laba; e)Perubahan pendapatan di masa lalu. Semakin besar perubahan pendapatan sebelum semakin tidak pasti pendapatan masa depan.

Adapun rumus yang digunakan untuk mengukur pertumbuhan laba menurut Fadhilah (2019) yaitu :

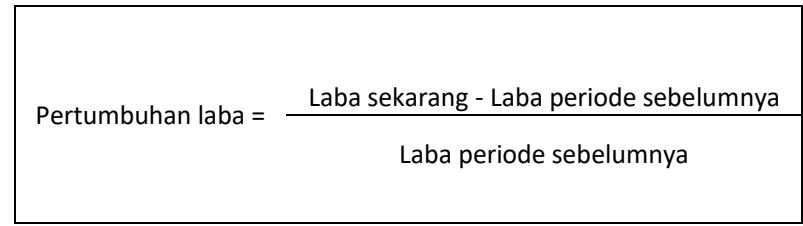

\subsection{Current Ratio dan Pertumbuhan Laba}

Menurut Olfiani \& Handayani (2019), current ratio berpengaruh terhadap pertumbuhan laba. Rasio ini merupakan rasio yang digunakan untuk mengukur kemampuan perusahaan dalam membayar kewajiban jangka pendek dengan menggunakan aktiva lancar yang dimiliki. Semakin mudah perusahaan membayar 
hutang jangka pendeknya maka semakin tinggi pula pengaruh terhadap pertumbuhan laba perusahaan tersebut.

Hipotesis 1. Current ratio berpengaruh terhadap pertumbuhan laba

\subsection{Total Asset Turnover dan Pertumbuhan Laba}

Menurut Utami (2018), TATO mempunyai pengaruh yang signifikan terhadap pertumbuhan laba. TATO merupakan rasio yang digunakan untuk mengukur perputaran semua aktiva yang dimiliki melalui penjualan. Hasil rasio ini dapat dikatakan tinggi apabila pemanfaatan aktiva secara maksimal akan menghasilkan penjualan yang tinggi, maka hasil dari rasio TATO semakin baik karena mampu menghasilkan laba yang tinggi.

Hipotesis 2. Total asset turnover berpengaruh terhadap pertumbuhan laba

\subsection{Return on Assets dan Pertumbuhan Laba}

Menurut Andriyani (2015), ROA berpengaruh signifikan terhadap pertumbuhan laba. Hal ini dapat terjadi apabila return on asset meningkat maka akan meningkatkan terjadinya aktivitas pertumbuhan laba, return on asset yang tinggi menunjukkan bahwa perusahaan berusaha meningkatkan penjualan atau pendapatan sehingga pertumbuhan laba juga ikut meningkat. Berarti perusahaan menunjukan bahwa, perusahaan berusaha meningkatkan penjualan atau pendapatan sehingga dengan begitu pertumbuhan laba juga ikut meningkat dengan sendirinya.

Hipotesis 3. Return on assets berpengaruh terhadap pertumbuhan laba

\subsection{Model Penelitian}

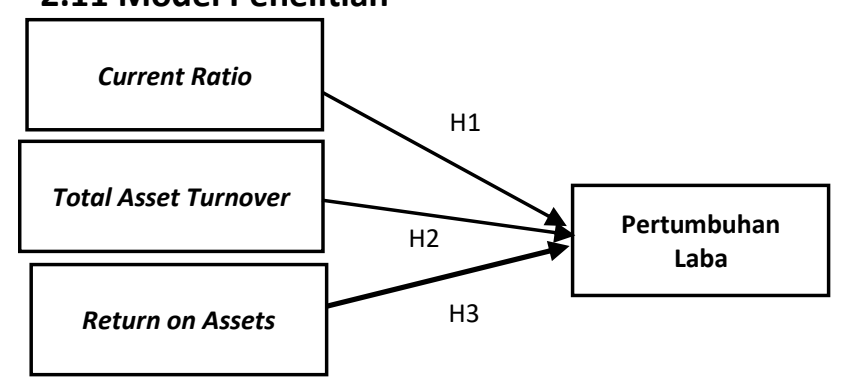

Gambar 1. Model Penelitian

Dari pembentukan hipotesis dibuat model penelitian pada Gambar. 1.

\section{Metodologi}

\subsection{Jenis Penelitian}

Penelitian ini merupakan penelitian kuantitatif yaitu jenis penelitian yang menghasilkan penemuan-penemuan yang dapat dicapai (diperoleh) dengan menggunakan prosedur-prosedur statistik atau cara-cara lain dari kuantifikasi (Sujarweni, 2019).

\subsection{Populasi dan Sampel}

Populasi pada penelitian ini yaitu seluruh laporan keuangan PT Gudang Garam Tbk. Pada penelitian ini menggunakan teknik pengambilan sampel yaitu teknik purposive sampling. Menurut Sanusi (2014:95) yaitu cara pengambilan sampel yang didasarkan pada pertimbanganpertimbangan tertentu. Peneliti mengambil teknik sampel ini karena terdapat informasi yang diberikan oleh sekelompok pakar yang memenuhi kriteria yang dibutuhkan oleh peneliti.

Pada penelitian ini menggunakan teknik pengambilan sampel yaitu teknik purposive sampling. Kriteria yang digunakan dalam pengambilan sampel yaitu seperti berikut: 1.Perusahaan PT Gudang Garam Tbk yang 
terdaftar di Bursa Efek Indonesia; 2.Laporan Keuangan Triwulan PT Gudang Garam Tbk tahun 2012-2019.

Tabel 1. Daftar Sampel Penelitian

\begin{tabular}{|c|c|}
\hline TAHUN & JUMLAH TRIWULAN \\
\hline 2012 & 4 \\
\hline 2013 & 4 \\
\hline 2014 & 4 \\
\hline 2015 & 4 \\
\hline 2016 & 4 \\
\hline 2017 & 4 \\
\hline 2018 & 4 \\
\hline 2019 & 4 \\
\hline Jumlah & 32 \\
\hline
\end{tabular}

Sumber: Data diolah, 2021

\subsection{Definisi Operasional Variabel}

Tabel 2. Definisi Operasional Variabel

\begin{tabular}{|c|c|c|c|}
\hline Variabel & \multicolumn{2}{|r|}{ Rumus } & Literatur \\
\hline \multirow[t]{2}{*}{$\mathrm{CR}$} & \multirow{2}{*}{$C R=$} & Aktiva Lancar & Kasmir(2017) \\
\hline & & Utang Lancar & \\
\hline \multirow[t]{2}{*}{ TATO } & \multirow{2}{*}{ TATO = } & Penjualan & $\begin{array}{l}\text { Fahmi } \\
(2020)\end{array}$ \\
\hline & & Total Aktiva & \\
\hline \multirow[t]{2}{*}{ ROA } & \multirow[t]{2}{*}{$\mathrm{ROA}=$} & Laba Bersih & $\begin{array}{l}\text { Hery } \\
(2015)\end{array}$ \\
\hline & & Total Aset & \\
\hline \multirow[t]{2}{*}{$\begin{array}{l}\text { Pertumbu } \\
\text { han Laba }\end{array}$} & \multirow{2}{*}{$\begin{array}{c}\text { Pertumb } \\
\text { uhan } \\
\text { Laba = }\end{array}$} & $\begin{array}{r}\text { Laba sekarang-laba } \\
\text { sebelumnya }\end{array}$ & $\begin{array}{l}\text { (FFrodthilah, } \\
\text { 2019) }\end{array}$ \\
\hline & & Laba period sebelur & inya \\
\hline
\end{tabular}

Sumber: Penulis, 2021

\subsection{Teknik Analisis}

\section{Uji Normalitas}

Menurut Ghozali (2016), uji normalitas bertujuan untuk menguji apakah dalam model regresi, variabel pengganggu atau residual memiliki distribusi normal. Model regresi yang baik yaitu mempunyai data normal atau mendekati normal. Untuk mendekati normalitas data dapat dilakukan melalui analisis statistik yang salah satunya dapat dilihat melalui Kolmogrov-Sminorv test (K-S). Menurut Ghozali
(2016), Uji K-S dapat dilakukan dengan membuat hipotesis:

$\mathrm{Ho}=$ Data residual terdistribusi normal

$\mathrm{H}_{\mathrm{a}}=$ Data residual tidak terdistribusi normal

Dasar pengambilan keputusan dalam uji K-S yaitu:

1. Apabila probabilitas nilai Z uji K-S signifikan statistik $(<0,05)$ maka Ho ditolak dan $\mathrm{H}_{\mathrm{a}}$ diterima yang berarti data terdistribusi tidak normal.

2. Apabila probabilitas nilai Z uji K-S tidak signifikan statistik $(>0,05)$ maka Hogagal diterima dan $\mathrm{H}_{a}$ ditolak, yang berarti data terdistribusi normal.

\section{Uji Multikolinearitas}

$$
\text { Menurut Sujarweni (2019), uji }
$$

multikolinearitas diperlukan untuk mengetahui ada tidaknya variabel independen yang memiliki kemiripan antar variabel independen dalam suatu model. Kemiripan antar variabel independen akan mengakibatkan korelasi yang sangat kuat. Selain itu uji ini juga untuk menghindari kebiasaan dalam proses pengambilan keputusan mengenai pengaruh pada uji parsial masing-masing variabel independen terhadap variabel dependen.

Menurut Ghozali (2011), multikolinearitas dapat dilihat dari nilai Tolerance dan lawannya Variance Inflation Factor (VIF). Kedua ukuran ini menunjukan setiap variabel bebas manakah yang dijelaskan oleh variabel bebas lainnya.Jadi, nilai tolerance yang rendah sama dengan nilai VIF tinggi. Nilai yang umum dipakai untuk 
multikolinearitas yaitu nilai tolerance $>0,10$ atau sama dengan nilai VIF $<10$.

\section{Uji Autokorelasi}

Uji Autokorelasi dapat dilakukan dengan menggunakan uji run test. Dalam pengujian ini didapatkan hipotesis jika antar residual tidak terdapat hubungan korelasi maka dikatakan bahwa residual yaitu acak atau random (Ghozali, 2016). Pengujian run test ini digunakan untuk melihat apakah suatu data residual terjadi secara acak atau tidak dengan taraf signifikansi 0,05. Jika hasil dari pengujian ini diatas taraf signifikansi maka persamaan regresi terbebas dari masalah autokorelasi.

\section{Uji Heteroskedastisitas}

$\begin{array}{crr}\text { Menurut } & \text { Sujarweni } & \text { (2008), } \\ \text { heteroskedastisitas } & \text { menguji } & \text { terjadinya }\end{array}$
perbedaan variance residual suatu periode pengamatan ke periode pengamatan yang lain. Cara memprediksi ada tidaknya heteroskedastisitas pada suatu model dapat dilihat dengan pola gambar Scatterplot, regresi yang tidak terjadi heteroskedastisitas jika :

1. Titik-titik data menyebar diatas dan dibawah atau disekitar angka 0.

2. Titik-titik data tidak mengumpul hanya diatas atau dibawah saja.

3. Penyebaran titik-titik data tidak boleh membentuk pola bergelombang melebar kemudian menyempit dan melebar kembali.

4. Penyebaran titik-titik data tidak berpola.

\section{Analisis Regresi Linier Berganda}

Menurut Sujarweni (2019), analisis regresi digunakan untuk mengetahui pengaruh antara variabel CR, TATO, dan ROA terhadap pertumbuhan laba. Selain itu juga analisis regresi digunakan untuk menguji kebenaran hipotesis yang diajukan dalam penelitian ini, yang dirumuskan seperti berikut:

$Y=a+b 1 X 1+b 2 X 2+b 3 X 3+e$

Dimana :

$Y=$ Pertumbuhan laba

X1 = Current Ratios

X2 = Total Assets Turn Over

$\mathrm{X} 3=$ Return On Assets

b1 = Koefisien Current Ratios

b2 $=$ Koefisien Total Assets Turn Over

b3 $=$ Koefisien Return On Assets

$\mathrm{a}=$ Konstanta

$\mathrm{e}=$ Variabel pengganggu

\section{Uji Hipotesis}

Menurut Ghozali (2016), uji statistik t pada dasarnya menunjukkan seberapa jauh individual dalam menerangkan variabel independen mempengaruhi variabel dependen.

Hipotesis dalam penelitian ini yaitu:

Ho = variabel bebas CR, TATO, dan ROA secara parsial tidak mempunyai pengaruh yang signifikan terhadap variabel terikat (pertumbuhan laba)

$\mathrm{Ha}=$ Variabel bebas CR, TATO, dan ROA secara parsial mempunyai pengaruh yang signifikan terhadap variabel terikat (pertumbuhan laba).

Dasar pengambilan keputusan menggunakan probabilitas yang signifikan, yaitu :

Apabila nilai signifikan $t>0,05$, HO diterima dan Ha ditolak 
Apabila nilai signifikan $t<0,05$ HO ditolak dan Ha diterima

\section{Hasil}

\subsection{Analisis Statistik Deskriptif}

Tabel 3. Hasil Analisis Statistik Deskriptif

\begin{tabular}{lcrrrr}
\hline & $\mathrm{N}$ & Min & Max & Mean & S. D \\
\hline Pertumbuhan Laba & 32 & -.21 & .40 & .1016 & .15302 \\
\hline Current ratio & 32 & 1.61 & 2.65 & 1.9522 & .28302 \\
\hline Total asset turnover & 32 & .27 & 1.40 & .7744 & .35331 \\
\hline Return on assets & 32 & .02 & .14 & .0664 & .03132 \\
\hline Valid N (listwise) & 32 & & & & \\
\hline Sumber: Data dion
\end{tabular}

Sumber: Data diolah, 2021

Hasil perhitungan diatas menunjukan bahwa PT Gudang Garam Tbk memiliki nilai rasio current ratio yang paling rendah dengan total nilai rasio sebesar 1.61. Nilai rasio current ratio bisa rendah disebabkan karena menurunnya jumlah aktiva lancar yang digunakan dalam membiayai hutang jangka pendeknya, berkurangnya jumlah aktiva lancar ini dapat disebabkan oleh operasional perusahaan yang menyebabkan jumlah aset perusahaan menurun. Untuk nilai rasio Total Assets Turn Over yang paling rendah dengan total nilai rasio sebesar 0.27 disebabkan karena menurunnya kemampuan perusahaan dalam menghasilkan penjualan, jadi akibat dari menurunnya kemampuan perusahaan ini dapat menyebabkan berkurangnya total aktiva yang dimiliki oleh perusahaan.

Nilai rasio Return On Assets yang paling rendah pada sebesar 0.02. Nilai rasio pada tahun ini bisa rendah disebabkan karena menurunnya kemampuan perusahaan dalam memperoleh aktiva sehingga menyebabkan berkurangnya laba bersih pada perusahaan. Untuk nilai pertumbuhan laba paling rendah pada sebesar 0.21 , pertumbuhan laba dapat dihitung dengan mengurangi laba tahun sekarang dengan laba tahun sebelumnya dan dibagi dengan laba tahun sebelumnya. Apabila nilai dari pertumbuhan laba negatif maka dapat disebabkan karena dipengaruhi oleh beberapa komponen atau faktor yang terdapat didalam laporan keuangan perusahaan.

Nilai rasio current ratio tertinggi dengan nilai sebesar 2.65 , dimana pada tahun ini total nilai aktiva mengalami peningkatan sehingga mampu membayar hutang jangka pendek perusahaan tersebut. Untuk rasio Total Assets Turn Over tertinggi nilai sebesar 1.40, dimana pada saat ini terjadi peningkatan penjualan yang menyebabkan meningkatnya total aktiva perusahaan. Untuk nilai rasio Return On Assets tertinggi dengan nilai sebesar 0.14 , dimana pada saat ini meningkatnya kemampuan perusahaan dalam menghasilkan laba bersih. Sedangkan nilai pertumbuhan laba tertinggi dengan nilai 0.40 , dimana karena laba bersih yang didapat perusahaan meningkat, maka pertumbuhan laba perusahaan juga meningkat besar.

\subsection{Hasil Uji Asumsi Klasik}

\section{Hasil Uji Normalitas}

Tabel 4. Hasil Uji Normalitas

\begin{tabular}{|l|r|}
\hline & Unstandardized Residual \\
\hline Kolmogorov-Smirnov Z & .888 \\
Asymp. Sig. (2-tailed) & .410 \\
\hline
\end{tabular}

Sumber: Data diolah, 2021 
Berdasarkan tabel pengujian diatas diketahui bahwa nilai signifikansi Asiymp.Sig (2tailed) sebesar 0,410 lebih besar dari 0,05. Maka sesuai dengan dasar pengambilan keputusan dalam uji normalitas kolmogorov-smirnov dapat disimpulkan bahwa data berdistribusi normal. Dengan demikian, asumsi normalitas dalam model regresi sudah terpenuhi.

\section{Hasil Uji Multikolinearitas}

Tabel 5. Hasil Uji Multikolinearitas

\begin{tabular}{|l|r|r|}
\hline \multirow{2}{*}{} & \multicolumn{2}{|c|}{ Collinearity Statistics } \\
\hline \multirow{2}{*}{ CR } & \multicolumn{1}{|c|}{ Tolerance } & \multicolumn{1}{c|}{ VIF } \\
\cline { 2 - 3 } TATO & .788 & 1.268 \\
ROA & .222 & 9.250 \\
& .423 & 7.390 \\
\hline
\end{tabular}

Sumber: Data diolah, 2021

Variabel CR : tolerance value sebesar 0,788 $>0,10$ dan VIF sebesar 1,268<10. Variabel TATO : tolerance value sebesar $0,222>0,10$ dan VIF sebesar 9,250< 10. Variabel ROA : tolerance value sebesar 0,423>0,10 dan VIF sebesar 7,390< 10. Maka dapat disimpulkan bahwa variabel CR, TATO dan ROA tidak terjadi Multikolinieritas.

\section{Hasil Uji Heterokedastisitas}

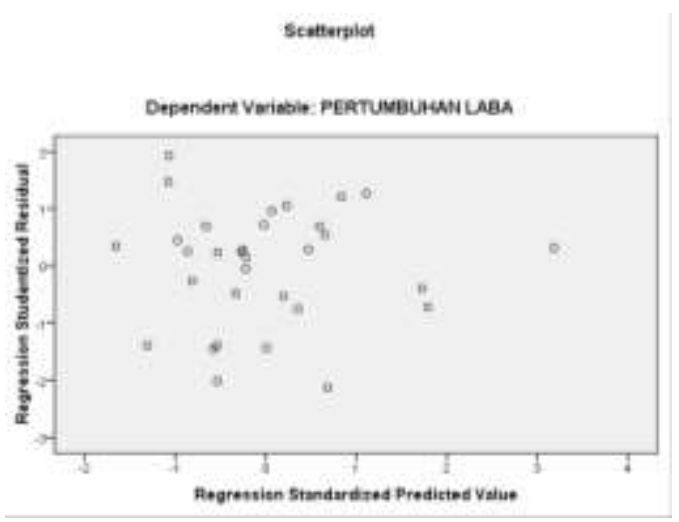

Gambar 2. Hasil Uji Heterokedastisitas

Berdasarkan output Scatterplots di atas diketahui bahwa:
1). Titik-titik data penyebar diatas dan dibawah atau sekitar angka 0 .

2). Titik-titik tidak mengumpul hanya di atas atau dibawah saja.

3). Penyebaran titik-titik data tidak membentuk pola bergelombang melebar kemudian menyempit dan melebar kembali.

4). Penyebaran titik-titik data tidak berpola.

\section{Hasil Uji Autokorelasi}

Tabel 6. Hasil Uji Autokorelasi Metode Run Test

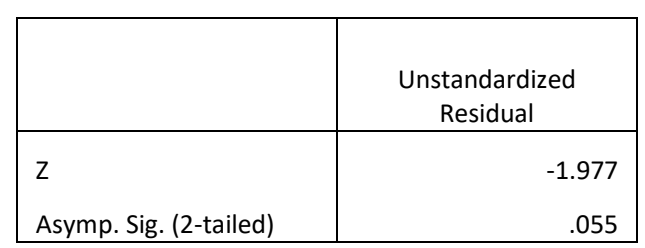

Sumber: Data diolah, 2021

Berdasarkan tabel uji Autokorelasi melalui metode run test, hasil nilai Asymp. Sig. (2-tailed) sebesar 0,055 > 0,05, maka pada uji autokorelasi ini dinyatakan tidak terdapat gejala atau masalah autokorelasi. Dengan demikian, analisis regresi linier berganda dapat dilanjutkan.

\subsection{Hasil Analisis Regresi Linier Berganda}

Tabel 7. Hasil Analisis Regresi

\begin{tabular}{|l|r|}
\hline Variabel & Regresi \\
\hline Konstanta (a) & 0.533 \\
\hline CR & -0.207 \\
\hline TATO & -1.477 \\
\hline ROA & 16.889 \\
\hline
\end{tabular}

Sumber: Data diolah, 2021

Artinya :

1). $a=0,533$ artinya apabila (X1), (X2) dan (X3) diasumsikan tidak memiliki pengaruh sama sekali $(=0)$ maka ( $\mathrm{Y}$ ) yaitu sebesar0,533.

2). b1 $=-0,207$ artinya apabila (X1) naik 1 (satu) satuan, (X2) dan (X3) tetap, maka (Y) akan turun sebesar $-0,207$ satuan. 
3). $b 2=-1,477$ artinya apabila (X2) naik 1 (satu) satuan, (X1) dan (X3) tetap, maka (Y) akan turun sebesar $-1,477$ satuan.

4). $b 3=16,889$ artinya apabila (X3) naik 1 (satu) satuan, (X1) dan (X2) tetap, maka (Y) akan naik sebesar 16,889 satuan.

\subsection{Hasil Uji Hipotesis}

Tabel 8. Hasil Uji t

\begin{tabular}{|l|r|l|}
\hline & $\mathrm{t}$ & Sig. \\
\hline CR & -2.143 & 0.041 \\
\hline TATO & -3.182 & 0.004 \\
\hline ROA & 3.271 & 0,003 \\
\hline
\end{tabular}

Sumber: Data diolah, 2021

Rumus $\mathrm{t}$ tabel $=\mathrm{a} / 2=0,025 ; d b: n-k-1=$ 32-3-1 = 28. Maka t tabel sebesar 2,04841.

Pada variabel X1 memperoleh nilai t hitung sebesar -2.143<-2,04841 t tabel, maka $\mathrm{H}_{1}$ dalam penelitian ini diterima dan $H_{o}$ ditolak. Dan variabel X1 memiliki tingkat signifikansi 0,041< 0,05 yang artinya variabel $\mathrm{X} 1$ secara parsial berpengaruh negatif signifikan terhadap variabel Y.

Pada variabel $\mathrm{X} 2$ memperoleh nilai t hitung sebesar $-3.182<-2,04841 \mathrm{t}$ tabel, maka $\mathrm{H}_{2}$ dalam penelitian ini diterima dan $\mathrm{H}_{\mathrm{o}}$ ditolak. Dan variabel X2 memiliki tingkat signifikansi 0,004< 0,05 yang artinya variabel X2 secara parsial berpengaruh negatif signifikan terhadap variabel Y.

Pada variabel $X 3$ memperoleh nilai t hitung sebesar $3.271>2,04841 \mathrm{t}$ tabel, maka $\mathrm{H}_{3}$ dalam penelitian ini diterima dan $H_{o}$ ditolak. Dan variabel X3 memiliki tingkat signifikansi 0,003 < 0,05 yang artinya variabel $\times 3$ secara parsial memiliki pengaruh positif signifikan terhadap variabel $\mathrm{Y}$.

\section{Pembahasan}

\subsection{Pengaruh current ratio terhadap pertumbuhan laba}

Hasil penelitian ini menunjukkan bahwa rasio lancar secara parsial berpengaruh negatif signifikan terhadap pertumbuhan laba. Temuan penelitian ini sejalan dengan temuan Olfiani dan Handayani (2019) yang menemukan bahwa Current Ratio berpengaruh besar terhadap pertumbuhan laba dalam penelitian mereka.

Current Ratio merupakan rasio yang digunakan untuk mengevaluasi kemampuan perusahaan untuk membayar dalam jangka pendek dengan menganalisis aset lancar. Semakin besar kemudahan yang perusahaan dapat bayar dalam jangka pendek, semakin tinggi nilai rasio ini. Hal ini menunjukkan bahwa hutang jangka pendek perusahaan melebihi keseluruhan aktiva lancarnya, sehingga mengakibatkan perusahaan mengalami kesulitan dalam melunasi kewajiban jangka pendeknya.

\subsection{Pengaruh total asset turnover terhadap} pertumbuhan laba

Hasil dalam penelitian ini menunjukkan bahwa TATO secara parsial berpengaruh negatif signifikan terhadap pertumbuhan laba. Hasil penelitian ini di dukung oleh penelitian Hamidu (2013) yang menyatakan bahwa TATO memiliki pengaruh signifikan terhadap pertumbuhan laba. Hal ini dapat terjadi karena kemampuan perusahaan dalam mengelola dan mebenefitkan aset-asetnya seperti penjualan tidak berjalan 
secara efektif, ketidak efektifan ini dapat terjadi karena perusahaan tidak memberikan manfaat secara keseluruhan aset yang dimiliki dalam menciptakan penjualan yang akan menghasilkan laba untuk perusahaan.

\subsection{Pengaruh return on assets terhadap pertumbuhan laba}

Hasil dalam penelitian ini menunjukkan bahwa ROA mempunyai pengaruh secara parsial terhadap pertumbuhan laba, hal ini juga didukung oleh penelitian Andriyani (2015) yang menyatakan bahwa ROA mempunyai pengaruh yang signifikan terhadap pertumbuhan laba. ROA merupakan salah satu dari rasio profitabilitas yang digunakan mengukur tingkat pendapatan dalam menghasilkan laba. Return On Assets yang tinggi menunjukkan bahwa perusahaan berusaha meningkatkan penjualan atau pendapatan sehingga pertumbuhan laba juga meningkat. Nilai Return On Assets yang tinggi menunjukkan bahwa perusahaan itu mulai berkembang yang akan memberikan laba yang tinggi, semua hal yang dilakukan perusahaan dapat menciptakan nilai yang tinggi serta perusahaan dapat mebenefitkan penggunaan aktiva yang dimiliki sehingga penggunaan aktiva yang baik akan menghasilkan laba yang maksimal.

\section{Kesimpulan dan Saran}

Current ratio berpengaruh negatif secara parsial terhadap pertumbuhan laba. Artinya Current Ratios tidak bisa digunakan untuk memprediksi pertumbuhan laba perusahaan. Total asset turnover berpengaruh negatif secara parsial terhadap pertumbuhan laba. Artinya total asset turnover tidak bisa digunakan untuk memprediksi pertumbuhan laba perusahaan. Return on assets berpengaruh positif terhadap pertumbuhan laba, artinya Return On Assets dapat digunakan untuk memprediksi pertumbuhan laba perusahaan..

Saran bagi perusahaan, pihak manajemen perusahaan lebih mengevaluasi secara tertus menerus mengenai kinerja perushaan sehingga akan tetap terlihat bagaimana keadaan perusahaan yang sedang mengalami peningkatan pertumbuhan laba maupun penurunan pertumbuhan laba. Dengan adanya evaluasi yang maksimal dan dilakukan secara terus menerus maka pihak perusahaan dapat mengetahui penyebab mengapa laba perusahaan naik ataupun turun sehingga dapat digunakan sepertipenentuan kebijakan yang bagus dalam mencapai profit yang optimal dimasa yang akan datang.

Bagi Stakeholders, hasil dari penelitian ini dapat digunakan seperti acuan dalam pengambilan kebijakan investasi. Jadi sebelum calon investor menanamkan modal ke perusahaan sebaiknya calon investor mempertimbangkan hasil dari penelitian ini dimana penelitian ini membahas tentang analisis rasio terhadap pertumbuhan laba dan hasil analisis ini dapat digunakan untuk memprediksi profit yang didapat oleh calon investor dimasa yang akan datang.

Bagi Peneliti Selanjutnya, hasil dari penelitian ini dapat digunakan seperti referensi bagi pihak peneliti selanjutnya dan sebaiknya 
juga menambahkan variabel lain atau menggunakan variabel lain serta memperbanyak jumlah sampel yang diteliti agar hasil penelitian menjadi lebih akurat dan tepat. Untuk masalah pertumbuhan laba pihak peneliti selanjutnya dapat menambahkan faktor-faktor lain selain rasio keuangan serta dapat menggunakan lebih dari perusahaan agar hasilnya lebih luas..

\section{Daftar Pustaka}

Andriyanti, I. (2015). Pengaruh Rasio Keuangan Terhadap Pertumbuhan Laba Pada Perusahaan Pertambangan Yang Terdaftar Di Bursa Efek Indonesia. Jurnal Manajemen Dan Bisnis Sriwijaya, 13(2), 344-358.

Ghozali, I. (2016). Aplikasi Analisis Multivariete Dengan Program IBM SPSS 23 (Edisi 8). Cetakan ke VIII, Semarang: Badan Penerbit Universitas Diponegoro.

Gunawan, A., \& Wahyuni, S. F. (2013). Pengaruh Rasio Keuangan Terhadap Pertumbuhan Laba Pada Perusahaan Perdagangan Di Indonesia. Jurnal Manajemen \& Bisnis, 13(1), 63-84.

Hamidu, N. P. (2011). Pengaruh Kinerja Keuangan Terhadap Pertumbuhan Laba Pada Perbankan Di BEI. Jurnal EMBA: Jurnal Riset Ekonomi, Manajemen, Bisnis Dan Akuntansi, 1(3), 711-721.

Hanafi, M. M., \& Halim, A. (2000). Analisis Laporan Keuangan. UPP AMP. YKPN.

Kasmir. (2017). Analisis Laporan Keuangan. Edisi Revisi, cetakan ke delapan. Jakarta : Rajawali Pers.

Munawir, S. (2004). Analisa Laporan Keuangan
Edisi Keempat, Yogyakarta: Liberty.

Olfiani, M., \& Handayani, M. (2019). Pengaruh Current Ratio (CR), Total Asset Turn Over (TATO), Dan Debt To Equity Ratio (DER) Terhadap Pertumbuhan Laba PT. Tempo Scan Pasific, Tbk Periode 2008-2017. Jurnal Ilmiah Akuntansi Dan Manajemen (JIAM), 15(2), 56-62.

Purnamasari, I. R. (2018). Pengaruh Rasio Keuangan Terhadap Pertumbuhan Laba Bank Pembiayaan Rakyat Syariah di Indonesia. Jakarta: Fakultas Ekonomi dan Bisnis UIN Syarif Hidayatullah.

Sanusi, Anwar. (2014). Metodologi Penelitian Bisnis. Edisi Pertama, cetakan keempat. Jakarta: Salemba Empat.

Sujarweni, V. W. (2017). Analisis Laporan Keuangan. Yogyakarta : Pustaka Baru Press. Sujarweni. (2008). Belajar Mudah SPSS untuk Penelitian Mahasiswa dan Umum. Edisi Pertama, cetakan pertama. Yogyakarta: Ardana Media.

Sujarweni. (2019). Metodologi Penelitian Bisnis dan Ekonomi. Edisi Pertama. Yogyakarta: Pustakabarupress. 